\title{
PENGEMBANGAN SISTEM PENDETEKSI BANJIR MENGGUNAKAN FUZZY DENGAN RASPBERRY PI (STUDI KASUS: KABUPATEN SAMPANG)
}

\author{
Dwi Puspitasari ${ }^{1}$, Muhammad Thaifururrahman $^{2}$, Rudy Ariyanto $^{2}$, \\ Jurusan Teknologi Informasi, Program Studi Teknik Informatika, Politeknik Negeri Malang \\ ${ }^{1}$ dwi.istari@gmail.com, ${ }^{2}$ muhammad.thaifururrahman@gmail.com, \\ 3ariyantorudy@gmail.com,
}

\begin{abstract}
Abstrak
Flood is a disastrous natural disaster for the people. Flooding occurs due to overflow of river, lake, or sewer water. Floods also result in material losses and even fatalities. Sampang regency is one of the districts in Madura Island that are often affected by floods. Raspberry Pi is a mini computer capable of performing the same task as a computer. The use of Raspberry Pi as a server is more efficient than using $P C$ Server which in terms of price is very expensive. Raspberry Pi can also be combined with various sensors because it has 40 pins as a connector. Ping Sensor Parallax is an ultrasonic sensor that can detect object distance by emitting ultrasonic waves with a frequency of $40 \mathrm{KHz}$ and then detecting its reflection. By using ultrasonic sensors as a tall water level counter it will be able to value the height of the river water. From this height value then processed by using fuzzy mamdani method so as to produce status of river water level. This altitude status will then be informed to the public. Based on the test results, this flood detection system uses ultrasonic sensors as a water level counters in control with Raspberry Pi. The data from the ultrasonic sensor is then calculated by the fuzzy mamdani method to produce the status of the water level. The water height status is obtained from the water level data calculated by using ultrasonic sensors. The water level status is then sent to the mobile phone number using the wavecom modem.
\end{abstract}

Kata kunci : Banjir, Raspberry Pi, Sensor Ultrasonik, Fuzzy Mamdani

Pendahuluan

Banjir merupakan suatu bencana alam yang meresahkan bagi masyarakat. Banjir terjadi akibat meluapnya air di sungai, danau atau selokan sehingga akan naik menggenangi daratan. Banyak kerugian yang ditimbulkan oleh banjir, bukan hanya berupa material, banjir juga bisa dapat menimbulkan korban jiwa.

Kabupaten Sampang merupakan salah satu area di Pulau Madura yang sering terkena banjir ketika hujan besar terjadi. Banjir terjadi akibat meluapnya Sungai Kemuning, karena tidak mampu menerima debit air di kawasan hulu di Sampang Utara dan limpahan banjir dari Kota Sampang. dan letak Kota Sampang berada pada posisi yang lebih rendah dari permukaan air laut pasang. Maka Kabupaten Sampang menjadi kabupaten yang paling rawan terjadi banjir ketika hujan lebat terjadi.

Untuk membantu masyarakat Kabupaten Sampang mengatasi permasalah ini dapat memanfaatkan terknologi yang ada. Dimana memungkinkan diciptakannya sebuah alat yang mampu mendeteksi ketinggian permukaan air. Sehingga mampu memberikan informasi status terkini kepada masyarakat akan terjadinya bencana banjir. Maka dari itu penulis ingin membuat sistem pendeteksi banjir yang memberikan informasi status ketinggian air sehingga mampu memberikan informasi disaat yang tepat.

Berawal dari permasalahan yang terjadi, maka dari itu penulis tertarik ingin melakukan perancangan sebuah sistem berbasis Raspberry $P i$ dengan menggunakan sensor ultrasonik sebagai pengukur tinggi permukaan air. Dengan hasil pengukuran dari sensor ini nanti akan di proses oleh Raspberry Pi sehingga akan mendapatkan hasil berupa status ketinggian permukaan air saat ini. Hasil status ketinggian permukaan air ini akan dikirimkan ke warga sekitar melalui sms.

\subsection{Banjir}

\section{Landasan Teori}

Menurut Undang-undang No.24 Tahun 2007, bencana didefinisikan sebagai peristiwa yang mengancam dan mengganggu kehidupan dan penghidupan masyarakat. Bencana dapat disebabkan baik oleh faktor alam atau faktor non alam maupun faktor manusia sehingga mengakibatkan timbulnya korban jiwa manusia, kerusakan lingkungan, kerugian harta benda, dan 
dampak psikologis.

Banjir didefinisikan sebagai tergenangnya suatu tempat akibat meluapnya air yang melebihi kapasitas pembuangan air disuatu wilayah dan menimbulkan kerugian fisik, sosial dan ekonomi [1]. Banjir adalah ancaman musiman yang terjadi apabila meluapnya tubuh air dari saluran yang ada dan menggenangi wilayah sekitarnya. Banjir adalah ancaman alam yang paling sering terjadi dan paling banyak merugikan, baik dari segi kemanusiaan maupun ekonomi [2].

Badang Penanggulangan Bencana Daerah Kabupaten Sampang

Badan Penanggulangan Bencana Daerah (BPBD) Kabupaten Sampang adalah sebuah lembaga pemerintah yang melaksanakan tugas penanggulangan bencana di Kabupaten Sampang dengan berpedoman pada kebijakan yang ditetapkan oleh Badan Nasional Penanggulangan Bencana.

Terdapat tiga aturan status ketinggian air sungai yang menjadi protokol standart di Kabupaten Sampang khususnya untuk Sungai Kamoning. Pertama, level hijau menunujukkan bahwa ketinggian air sungai masih nomal dengan tinggi kurang lebih 1 meter. Kedua, level kuning menunjukkan bahwa ketinggian air sungai sudah dalam keadaaan siaga dengan ketinggian air kurang lebih 2 meter. Ketiga, level merah dengan ketinggian kurang lebih 2,75 meter menunjukkan bahwa ketinggian sudah mencapai keadaan darurat dan terdapat pemberitahuan kepada masyarakat akan terjadinya banjir

Raspberry Pi

Raspberry Pi merupakan komputer mini yang memiliki ukuran kecil yaitu sebesar kartu ATM tetapi mampu menjalankan tugas yang sama dengan komputer PC. Tetapi di lapangan kebanyakan aplikasi web server tidak akan menangani sebegitu banyak permintaan sehingga bakal tidak akan memanfaatkan sepenuhnya potensi dari hardware yang dimilikinya. Pada gambar 2.1 ditunjukkan gambar dari raspberry pi 3.

Dengan menggunakan Raspberry $P i$ sebagai server lebih efisien dari pada menggunakan PC Server yang dari segi harga sangat mahal.[3] Salah satu produk Raspberry Pi yaitu Raspberry Pi 3 model B yang merupakan generasi penerus dari Raspberry Pi 2 model B. Harga dari Raspberry Pi 3 model B ini US\$33.96, cukup terjangkau dibandingkan jika membeli sebuah PC untuk digunakan komputasi yang sederhana. Kelebihan lainnya yaitu ukurannya yang kecil dan konsumsi daya listrik yang rendah menjadikannya sangat cocok untuk berbagai keperluan.

Python

Python merupakan bahasa pemerograman tingkat tinggi (high level language) yang dikembangkan oleh Guido van Rossum pada tahun 1989 dan diperkenalkan untuk pertama kalinya pada tahun 1991. Python lahir atas dasar keinginan untuk mempermudah seorang programmer dalam menyelesaikan tugas-tugasnya dengan cepat. Python dirancang untuk memberikan kemudahan yang sangat luar biasa kepada programmer baik dari segi efisiensi waktu, maupun kemudahan dalam pengembangan program dan dalam hal kompatibilitas dengan system. Python bisa digunakan untuk membuat program standalone dan pemrograman skrip (scripting programming).[4]

Sisi utama yang membedakan Python dengan bahasa lain adalah dalam hal aturan penulisan kode program. Bagi para programmer di luar python siap-siap dibingungkan dengan aturan indentasi, tipe data, tuple, dan dictionary. Python memiliki kelebihan tersendiri dibandingkan dengan bahasa lain terutama dalam hal penanganan modul, ini yang membuat beberapa programmer menyukai Python. Selain itu Python merupakan salah satu produk yang open source, free, dan multi platform.

\section{Sensor Ping Parallax}

Sensor Ping merupakan sensor ultrasonik yang dapat mendeteksi jarak objek dengan cara memancarkan gelombang ultrasonik dengan frekuensi $40 \mathrm{KHz}$ dan kemudian mendeteksi pantulannya. Dengan sensor ini maka ketinggian air sungai dapat terdeteksi. Pada modul Ping terdapat 3 pin yang digunakan untuk jalur power supply $(+5 \mathrm{~V})$, ground dan signal.

\section{Modem GSM Wavecom}

Wavecom merupakan salah satu pabrikan yang berasal dari Perancis. Perusahaan tersebut mulai dikenal di Indonesia dengan menyediakan modem Wavecom yang multi fungsi. Salah satu fungsinya yaitu untuk membantu kegiatan industri bisnis rumahan yang membutuhkan layanan SMS gateway dan lain-lain. Contohnya pada server pulsa yang membutuhkan banyak modem pengirim SMS yang bekerja secara otomatis dalam menerima setiap transaksi, membalas report dan lain-lain

\section{Fuzzy}


Konsep tentang logika Fuzzy diperkenalkan oleh Prof. Lotfi Astor Zadeh pada 1962. Logika Fuzzy adalah metodologi sistem kontrol pemecahan masalah, yang cocok untuk diimplementasikan pada sistem, mulai dari sistem yang sederhana, sistem kecil, embedded system, jaringan PC, multichannel atau workstation berbasis akuisisi data, dan sistem kontrol. Metodologi ini dapat diterapkan pada perangkat keras, perangkat lunak, atau kombinasi keduanya. Dalam logika klasik dinyatakan bahwa segala sesuatu bersifat biner, yang artinya adalah hanya mempunyai dua kemungkinan, "Ya atau Tidak", "Benar atau Salah", "Baik atau Buruk", dan lainlain. Oleh karena itu, semua ini dapat mempunyai nilai keanggotaan 0 atau 1 . Akan tetapi, dalam logika Fuzzy kemungkinan nilai keanggotaan berada diantara 0 dan 1 . Artinya,bisa saja suatu keadaan mempunyai dua nilai "Ya dan Tidak", "Benar dan Salah", "Baik dan Buruk" secara bersamaan, namun besar nilainya tergantung pada bobot keanggotaan yang dimilikinya.[5]

Metode Mamdani paling sering digunakan dalam aplikasi-aplikasi karena strukturnya yang sederhana, yaitu menggunakan operasi MINMAX atau MAX-PRODUCT. Untuk mendapatkan output, diperlukan empat tahapan berikut [6] :

a. Fuzzyfikasi.

b. Pembentukan basis pengetahuan Fuzzy (rule dalam bentuk $I F \ldots T H E N$ ).

c. Aplikasi fungsi implikasi menggunakan fungsi MIN dan Komposisi antar-rule menggunakan fungsi MAX (menghasilkan himpunan Fuzzy baru).

d. Defuzzyfikasi menggunakan metode Centroid.

$$
Z=\frac{\int u(z) z d z}{\int u(z) d z}
$$

3 Metodologi Penelitian

Pada bagian ini akan dibahas metodologi yang digunakan peneliti dalam pembuatan Pengembangan Sistem Pendeteksi Banjir Menggunakan Fuzzy dengan Raspberry Pi (Studi Kasus : Kabupaten Sampang). Metode penelitian yang digunakan adalah metode modified waterfall. Metode modified waterfall bisa dijelaskan pada Gambar 1 dibawah ini :

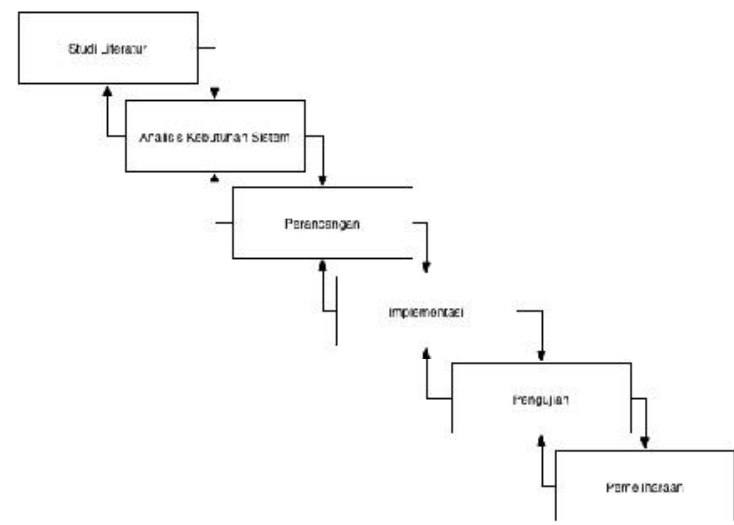

Gambar 1 Metodologi Penelitian

\subsection{Studi Literatur}

Pada tahap ini dilakukan pencarian referensi, jurnal, artikel, majalah ilmiah yang berkaitan dengan pendeteksi banjir, raspberry pi, sensor ultrasonik, fuzzy mamdani, dan sms gateway untuk membantu dan membimbing dalam proses pembuatan sistem.

\subsection{Analisa Kebutuhan Sistem}

Pada tahap ini yaitu pengumpulan kebutuhan fungsional sistem yang nantinya akan digunakan. Kebutuhan tersebut bisa berupa kebutuhan hardware maupun software. Sedangkan untuk pengaplikasian sistem dibutuhkan sebuah prototipe yang digunakan untuk penelitian ini dan juga untuk menguji bagaimana sistem ini berjalan dalam pengaplikasiannya.

\subsection{Perancangan}

Pada tahap perencanaan dibagi menjadi dua bagian. Yaitu perancangan hardware dan perancangan software.

1. Perancangan hardware

Pada perancangan hardware, menjelaskan penggunaan alat yang dipakai juga spesifikasinya

\section{Perancangan software}

Pada perancangan software, menjelaskan tentang perancangan aristektur sistem, prototipe, juga berbagai rancangan yang berhubungan dengan sistem.

\subsection{Implementasi}

Implementasi sistem ini terdapat beberapa tahapan yaitu :

- Instalasi RaspbianOS

RaspbianOS merupakan sistem operasi yang digunakan untuk perangkat raspberry Pi.

- Konfigurasi Raspberry Pi

Setelah raspberry berjalan, koneksikan dengan internet, kemudian update, upgrade paketpaket yang ada di raspberry Pi. Setelah proses update dan upgrade selesai, selanjutnya memasukkan paket yang dibutuhkan raspberry pi seperti : 
a.Python 3

b. Modul library Python-Rpi.GPIO

c.Modul library Scikit-Fuzzy

d. Pembuatan script program pada raspberry pi

- Implementasi Arsitektur Sistem

- Implementasi Program

- Implementasi User Interface

3.5 Pengujian

Tahapan pengujian pada sistem yang telah dibuat pada masalah yang didapatkan, pengujian pada sensor, modem sms, aplikasi, yang memakai pengujian black-box, dan juga prototipe.

\subsection{Pemeliharaan}

Tahap terakhir dari model modified waterfall yaitu pemeliharaan. Terdapat beberapa jenis pemeliharaan yang dapat dilakukan salah satunya yaitu Corrective Maintenance. Corrective Maintenance merupakan pemeliharaan ketika sistem telah berjalan kemudian baru ditemukan suatu kesalahan atau kekurangan pada sistem.

\section{Implementasi \\ 4.1 Implementasi arsitektur sistem}

Gambar 2 merupakan komponen elektronika untuk menyambungkan pin GPIO pada raspberry pi dengan jumper, tanpa menggunakan breadboard kita bisa menyambungkannya dengan jumper, akan tetapi jumlah maksimum dari jumper menjadi terbatas, dan perangkat ini bisa membuat jumlah masukan jumper jadi lebih banyak.

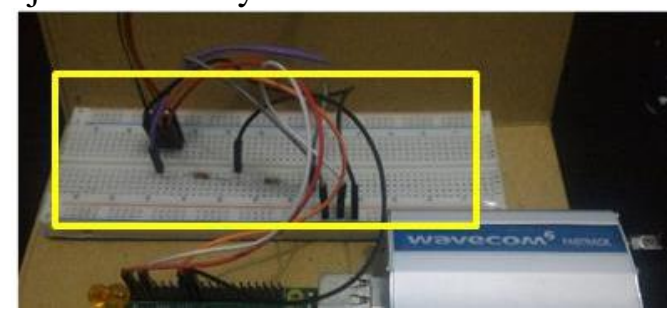

Gambar 2 Breadboard GPIO

Gambar 3 merupakan salah satu komponen elektronika yang dinamakan dengan sensor Ultrasonik Ping Parallax. Sensor ultrasonik yang dapat mendeteksi jarak objek dengan cara memancarkan gelombang ultrasonik dengan frekuensi $40 \mathrm{KHz}$ dan kemudian mendeteksi pantulannya.

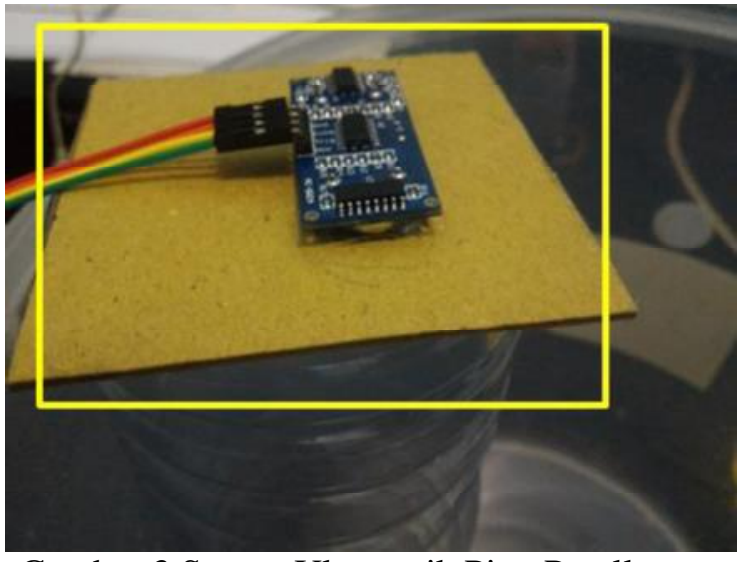

Gambar 3 Sensor Ultrasonik Ping Parallax

Gambar 4 merupakan modem gsm wavecome. Modem ini berfungsi sebagai penyalur informasi kepada masyarakat melalui sms.

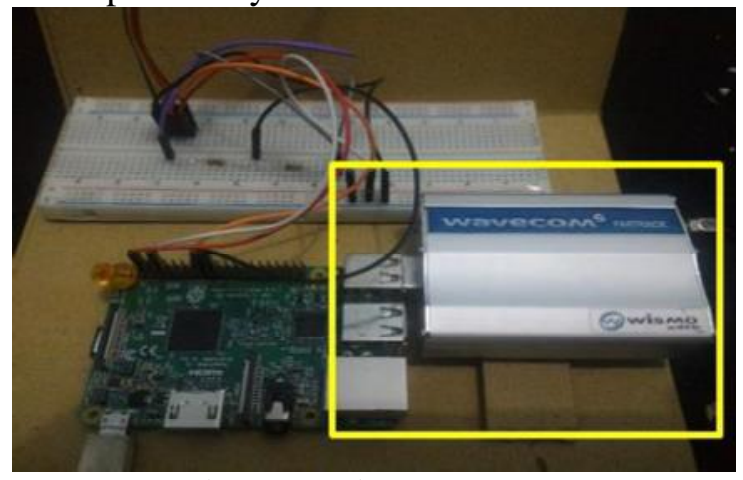

Gambar 4 Modem Wavecom

Menu Utama pada aplikasi pendeteksi banjir terdapat dua bagian. Bagian pertama merupakan status dari ketinggian air dan kecepatan air saat ini. Dan bagian kedua merupakan data nomor handphone. Gambar 5 merupakan tampilan menu utama.

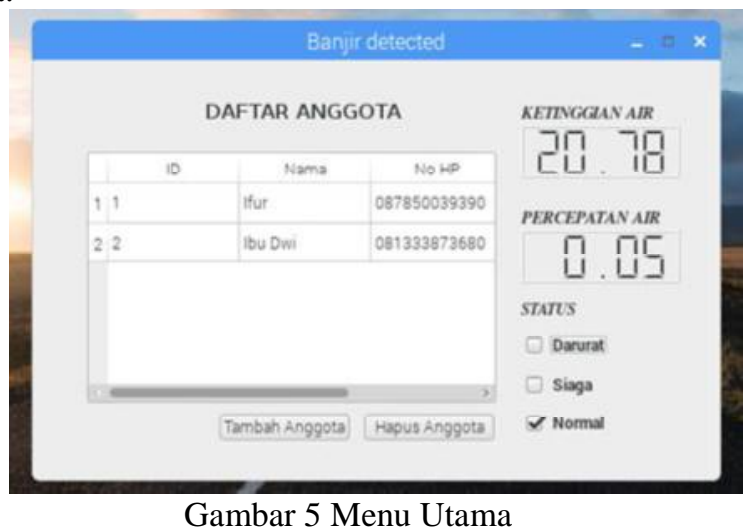

5 Uji Coba dan Pembahasan

5.1 Uji Coba Koneksi 
Jurnal Teknologi Informatika dan Terapan Vol. 04, No 02, Juli - Desember 2017 ISSN: 235-838X

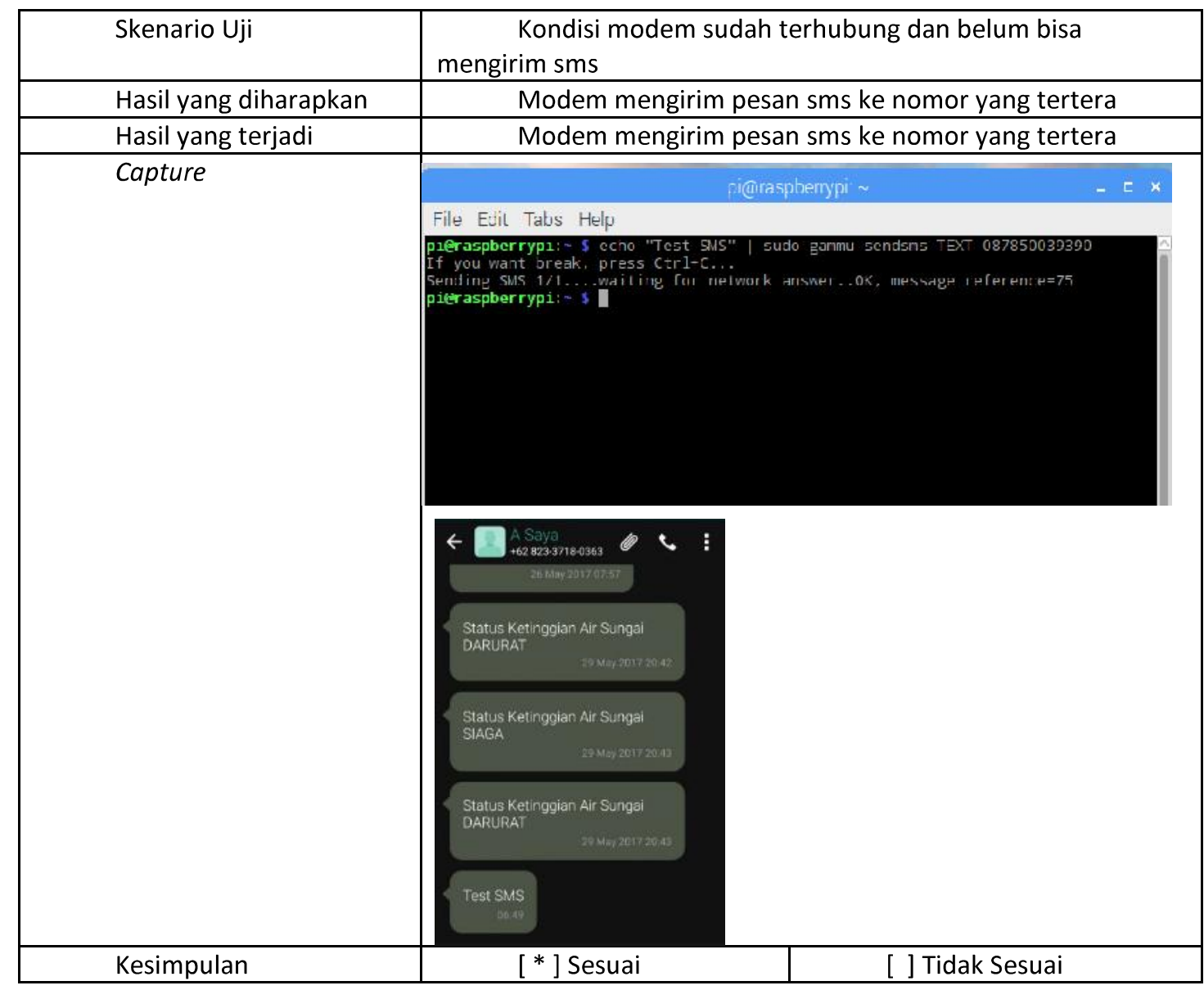




\subsection{Uji Coba Fungsional}

Tabel 2 Uji Coba Fungsional

\begin{tabular}{|c|c|c|c|c|c|}
\hline No & Case & Input & Validasi & Hasil Uji & Status \\
\hline \multirow[t]{2}{*}{1} & \multirow[t]{2}{*}{$\begin{array}{l}\text { Tambah } \\
\text { Anggota }\end{array}$} & \multirow[t]{2}{*}{$\begin{array}{l}\text { Id, Nama, } \\
\text { Nomor } \\
\text { handphon } \\
\text { e }\end{array}$} & Data valid & $\begin{array}{l}\text { Data } \\
\text { berhasil } \\
\text { disimpan }\end{array}$ & \multirow[t]{2}{*}{ Diterima } \\
\hline & & & $\begin{array}{l}\text { Data } \\
\text { invalid }\end{array}$ & $\begin{array}{l}\text { Data } \\
\text { disimpan } \\
\text { tidak } \\
\text { menerima } \\
\text { pesan sms }\end{array}$ & \\
\hline 2 & $\begin{array}{l}\text { Hapus } \\
\text { Anggota }\end{array}$ & $\begin{array}{l}\text { Tombol } \\
\text { hapus } \\
\text { ditekan }\end{array}$ & & $\begin{array}{l}\text { Data } \\
\text { anggota } \\
\text { dihapus }\end{array}$ & Diterima \\
\hline 3 & $\begin{array}{l}\text { Status } \\
\text { Normal }\end{array}$ & $\begin{array}{l}\text { Sensor } \\
\text { ultrasonik }\end{array}$ & $\begin{array}{l}\text { Ketinggian } \\
\text { air kurang } \\
\text { dari } 13,9 \\
\mathrm{~cm}\end{array}$ & $\begin{array}{l}\text { Status } \\
\text { Normal }\end{array}$ & Diterima \\
\hline 4 & $\begin{array}{l}\text { Status } \\
\text { Siaga }\end{array}$ & $\begin{array}{l}\text { Sensor } \\
\text { ultrasonik }\end{array}$ & $\begin{array}{l}\text { Ketinggian } \\
\text { air lebih } \\
\text { dari } 14 \mathrm{~cm} \\
\text { dan } \\
\text { kurang } \\
\text { dari } 17,9 \\
\mathrm{~cm}\end{array}$ & $\begin{array}{l}\text { Status } \\
\text { Siaga dan } \\
\text { pesan sms } \\
\text { akan } \\
\text { dikirim }\end{array}$ & Diterima \\
\hline 5 & $\begin{array}{l}\text { Status } \\
\text { Darurat }\end{array}$ & $\begin{array}{l}\text { Sensor } \\
\text { ultrasonik }\end{array}$ & $\begin{array}{l}\text { Ketinggian } \\
\text { air lebih } \\
\text { dari } 18 \mathrm{~cm}\end{array}$ & $\begin{array}{l}\text { Status } \\
\text { Darurat } \\
\text { dan pesan } \\
\text { akan } \\
\text { dikirim }\end{array}$ & Diterima \\
\hline
\end{tabular}

\subsection{Uji Coba Penggunaan Metode Fuzzy}

Uji coba pada metode fuzzy ini dengan memberi contoh nilai dari suatu ketinggian air dan kecepatan ketinggian air. Dimana nilai tersebut nantinya akan digunakan untuk bekerjanya metode yang dipakai yaitu metode fuzzy mamdani. Metode ini akan berjalan dengan aturan yang telah dibuat. Kemudian dari aturan tersebut akan keluar hasil berupa status ketinggian air. excel.

Perhitungan manual dilakukan pada microsoft

Dengan contoh nilai ketinggian air $18 \mathrm{~cm}$ dan kecepatan $2.2 \mathrm{~cm}$. Status apa yang akan didapatkan ?

Solusi.

- Pembentukan Himpunan Fuzzy

Ada 3 variabel fuzzy yang akan dimodelkan, yaitu:

1. Ketinggian, terdiri-atas 3 himpunan fuzzy, yaitu: Rendah, Sedang, dan Tinggi (Gambar 6).

Fungsi keanggotaan variabel Ketinggian pada sebagai berikut

$$
\begin{aligned}
\mu \mathrm{KtRendah} & =\left\{\begin{array}{cc}
1, & x \leq 8 \\
\frac{17-x}{17-8} & 8 \leq x \leq 17 \\
0 & x \geq 17
\end{array}\right. \\
\mu \mathrm{KtSedang} & =\left\{\begin{array}{cc}
0, & x \leq 8 \text { atau } x \geq 23 \\
\frac{x-8}{17-x} & 8 \leq x \leq 17 \\
\frac{23-x}{23-17} & 17 \leq x \leq 23
\end{array}\right.
\end{aligned}
$$

$\mu \mathrm{KtTinggi}=\left\{\begin{array}{cc}0, & x \leq 17 \\ \frac{x-17}{23-17} & 17 \leq x \leq 23 \\ 1 & x \geq 25\end{array}\right.$

Kita bisa mencari nilai keanggotaan:

$\mu \mathrm{KtSedang}[18]=(23-18) / 6=0.83$

$\mu \mathrm{KtTinggi}[18] \quad=(18-17) / 6=0.17$

2.Kecepatan, terdiri-atas 3 himpunan fuzzy, yaitu:

Lamban, Sedang, dan Cepat (Gambar 7). berikut:

Fungsi keanggotaan variabel Kecepatan pada sebagai

$$
\mu \mathrm{KcLamban}=\left\{\begin{array}{cc}
1, & x \leq 1 \\
\frac{2-x}{2-1} & 1 \leq x \leq 2 \\
0 & x \geq 2
\end{array}\right.
$$

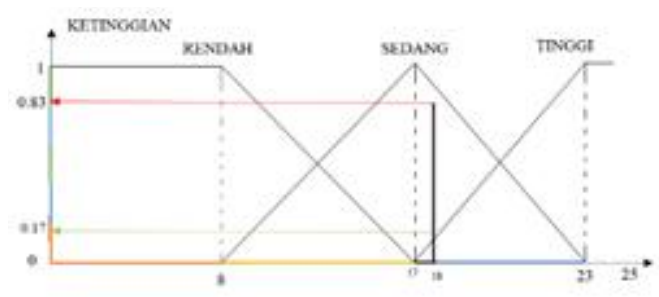

Gambar 5 Fungsi Keanggotaan dari Variabel Ketinggian

$$
\begin{aligned}
& \mu \mathrm{KtSedang}=\left\{\begin{array}{cc}
0, & x \leq 1 \text { atau } x \geq 3 \\
\frac{x-2}{2-1} & 1 \leq x \leq 3 \\
\frac{3-x}{3-2} & 2 \leq x \leq 3
\end{array}\right. \\
& \mu \mathrm{KtCepat}=\left\{\begin{array}{cc}
0, & x \leq 2 \\
\frac{x-2}{3-2} & 2 \leq x \leq 3 \\
1 & x \geq 3
\end{array}\right.
\end{aligned}
$$

Kita bisa mencari nilai keanggotaan: $\mu$ KcSedang[2,2] $=(3-2.2) / 1=0.8$ $\mu$ KtTinggi $[2,2]=(2.2-2) / 1=0.17$

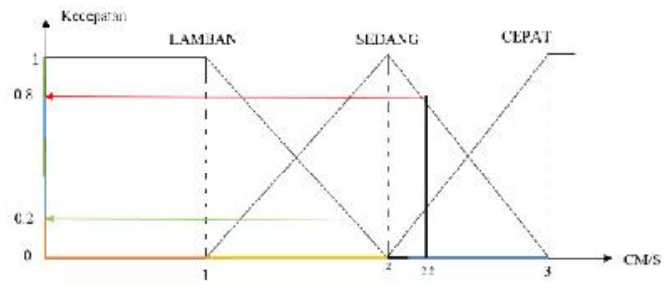

\section{Gambar 6 Fungsi Keanggotaan dari Variabel Kecepatan}

3.Status, terdiri-atas 3 himpunan fuzzy, yaitu:

Normal, Siaga, dan Darurat (Gambar 6.4 ).

Fungsi keanggotaan variabel Status pada sebagai berikut:

$\mu$ StNormal $=\left\{\begin{array}{cc}1, & x \leq 8 \\ \frac{17-x}{17-8} & 8 \leq x \leq 17 \\ 0 & x \geq 17\end{array}\right.$ 


$$
\begin{gathered}
\mu \text { StSiaga }=\left\{\begin{array}{cc}
0, & x \leq 8 \text { atau } x \geq 23 \\
\frac{x-8}{17-x} & 8 \leq x \leq 17 \\
\frac{23-x}{23-17} & 17 \leq x \leq 23
\end{array}\right. \\
\mu \text { StDarurat }=\left\{\begin{array}{cc}
0, & x \leq 17 \\
\frac{x-17}{23-17} & 17 \leq x \leq 23 \\
1 & x \geq 25
\end{array}\right.
\end{gathered}
$$

- Aplikasi metode implikasi

[R5] IF Ketinggian sedang And Kecepatan Sedang THEN Status Ketinggian Siaga;

$\alpha$-predikat $1=\mu \mathrm{KtSedang} \cap \mu \mathrm{KcSedang}$

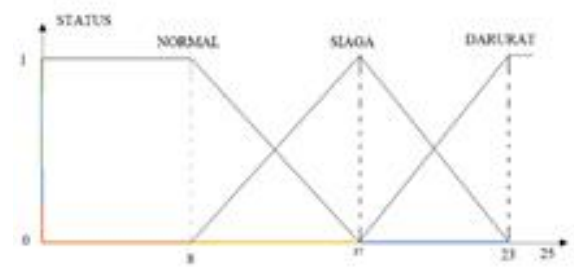

Gambar 7 Fungsi Keanggotaan dari Variabel Status

$=\min (\mu \mathrm{KtSedang}[18], \mu \mathrm{KcSedang}[2,2])$

$=\min (0.83 ; 0,8)$

$=0.8$

[R6] IF Ketinggian Sedang And Kecepatan Tinggi THEN Status Ketinggian Darurat;

$\alpha$-predikat $1=\mu \mathrm{KtSedang} \cap \mu \mathrm{KcSTinggi}$

$=\min (\mu \mathrm{KtSedang}[18], \mu$ KcTinggi $[2,2])$

$=\min (0.83 ; 0,2)$

$=0.2$

[R8] IF Ketinggian Tinggi And Kecepatan Sedang THEN Status Ketinggian Darurat;

$\alpha$-predikat $1=\mu \mathrm{KtTinggi} \cap \mu \mathrm{KcSedang}$

$=\min (\mu \mathrm{KtSedang}[18], \mu \mathrm{KcSedang}[2,2])$

$=\min (0,17 ; 0,8)$

$=0.17$

[R9] IF Ketinggian Tinggi And Kecepatan Tinggi THEN Status Ketinggian Darurat;

$\alpha$-predikat $1=\mu \mathrm{KtTinggi}_{1} \cap \mu \mathrm{KcTinggi}$

$=\min (\mu \mathrm{KtSedang}[18], \mu \mathrm{KcSedang}[2,2])$ $=\min (0.17 ; 0,2)$

$=0.2$

- Komposisi Aturan

Dari hasil aplikasi fungsi implikasi dari tiap aturan, digunakan metode MAX untuk melakukan komposisi antar semua aturan. Hasilnya seperti pada Gambar 9.

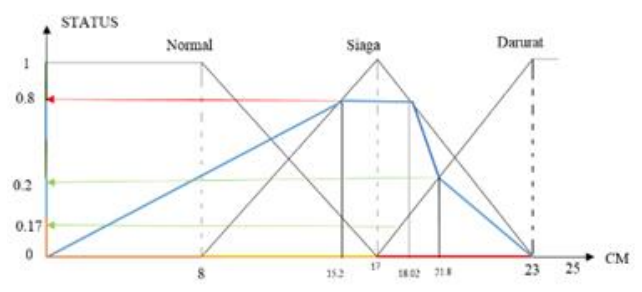

\section{Gambar 8 Hasil Daerah Komposisi Aturan (Area Garis Biru )}

- Defuzzyfikasi

Metode penegasan yang akan kita gunakan adalah metode centroid.

$$
\begin{aligned}
& \mathrm{Z}= \\
& \frac{\int_{0}^{15.2} 0.8 x d x+\int_{15.2}^{17} 0.8 x d x+\int_{17}^{18.02} 0.8 x d x+\int_{18.02}^{21.8}\left(\frac{23-x}{23-17}\right) x d x+\int_{21.8}^{23} 0.2 x d x}{\left(\frac{15.2 * 0.8}{2}\right)+(0.8 *(18.02-15.12))+\left(((21.8-18.02) * 0.2)+\left(\frac{0.6 *(21.8-18.02)}{2}\right)+\left(\frac{0.2 *(23-21.8}{2}\right)\right.} \\
& =\frac{92.416+23.184+14.288816+38.00+5.376}{6.08+2.32+1.89+0.24} \\
& =\frac{173.264816}{10.53}=16.4=16(\text { siaga })
\end{aligned}
$$

5.4 Pembahasan Koneksi

Pembahasan terhadap uji coba koneksi dengan melihat pada hasil kinerja modem gsm wavecom yang terdapat pada Tabel 1 dapat diketahui bahwa untuk koneksi sms ke nomor handphone terkoneksi dengan baik. Hal ini sangat berpengaruh kepada sistem pendeteksi banjir agar bisa langsung memberikan informasi status ketinggian air sungai kepada masyarakat.

\subsection{Pembahasan Fungsional}

Pembahasan terhadap uji coba fungsional yang dilakukan dengan melihat antara hasil kerja sistem dengan daftar uji coba pada Tabel 2 bisa disimpulkan sistem sudah berjalan dengan baik. Sehingga bisa dikatakan bahwa implementasi dan fungsionalis sistem pendeteksi banjir dapat berjalan sesuai dengan rancangan. 


\subsection{Pembahasan Metode}

Pembahasan terhadap uji coba metode yang diterapkan pada sistem ini telah diaplikasikan. Pada hasil tersebut menunjukkan bahwa sistem sudah berjalan sesuai dengan aturan metode fuzzy mamdani

6. Kesimpulan dan Saran

\subsection{Kesimpulan}

Berdasarkan penelitian yang telah dilakukan penulis mengenai "Pengembangan Sistem Pendeteksi Banjir Menggunakan Fuzzy dengan Raspberry Pi" maka dapat diambil kesimpulan bahwa :

- Penelitian ini telah berhasil membuat sistem yang digunakan untuk mengetahui status ketinggian air yang diterapkan pada raspberry pi dengan menggunakan sensor ultrasonik.

- Dengan menggunakan modem gsm wavecome, sistem ini berhasil mengirim pesan status ketinggian air pada nomor handphone yang sudah tersimpan pada sistem pendeteksi banjir.

\subsection{Saran}

Saran yang didapat pada untuk pengembangan sistem ini adalah dengan dibuatkan untuk versi website ataupun androidnya agar mengikuti perkembangan dunia informasi teknologi. Serta penambahan sensor curah hujan dan anemometer supaya sistem ini semakin lengkap.

\section{Daftar Pustaka}

[1] Rahayu. Dkk. (2009). Banjir dan Upaya Penanggulangannya. Bandung : Pusat Mitigasi Bencana (PMB-ITB)

[2] IDEP, 2007. Panduan Umum Penanggulangan Bencana Berbasis Masyarakat, Edisi Ke-2, Bali : Yayasan IDEP.

[3] Rahmad Dawood, et all., 2014. Kelayakan Raspberry Pi sebagai Web Server. Jurnal Rekayasa Elektrika

[4] Sianipar, H., R., et all., 2015. Pemrograman PYTHON (Teori dan Implementasi). Bandung: Informatika

[5] Parallax. PING))) ${ }^{\mathrm{TM}}$ Ultrasonic Distance Sensor (\#28015 ) V1.3, hlm. 1-13, California: Parallax, 2006

[6] Sutojo, T., et all., 2011. Kecerdasan Buatan. Yogyakarta: ANDI 